\title{
Peningkatan Kemampuan Menulis Naskah Drama melalui Pendekatan Kontekstual Berbasis Cerita Rakyat Musi Rawas Siswa Kelas VIII SMP Negeri Pedang
}

\author{
Arie Lasmiyanti, Sarwit Sarwono, Gumono \\ Program Magister Pendidikan Bahasa Indonesia, Universitas Bengkulu \\ Corresponding email: lasmiyanti@yahoo.com
}

\begin{abstract}
The purpose of this study was to describe the improvement in writing drama scripts through a contextual approach based on the folklore Musi Rawas grade VIII students of SMP Negeri Pedang. This type of research is classroom action research. The data source of this research is VIII grade students of SMP Negeri Pedang in the 2018/2019 academic year, while the research data is the ability to write media-based drama scripts of Musi Rawas folklore. Data collection techniques using test, observation, and documentation techniques. The study was conducted in two cycles, each cycle designed with the details of the activities of each meeting as follows: (1) planning, (2) action, (3) observation, and (4) reflection. Test the validity of the data using triangulation. The results of this study indicate that there was an increase in the ability to write drama scripts for VIII grade students of SMP Negeri Pedang by using a contextual approach based on Musi Rawas folklore. This is indicated by an increase in learning outcomes from cycle 1 to cycle 2 . In cycle 1 students who completed $44.5 \%$ with enough categories and an increase in cycle 2 with the number of students who completed $86.1 \%$ with good categories.
\end{abstract}

Keywords: Writing Drama Scripts, Contextual Approaches, Folklore

\begin{abstract}
Abstrak
Tujuan penelitian ini untuk mendeskripsikan peningkatan menulis naskah drama melalui pendekatan kontekstual berbasis cerita rakyat Musi Rawas siswa kelas VIII SMP Negeri Pedang. Jenis penelitian yang digunakan adalah penelitian tindakan kelas. Sumber data penelitian ini adalah siswa kelas VIII SMP Negeri Pedang tahun pelajaran 2018/2019, sedangkan data penelitian berupa kemampuan menulis naskah drama berbasis media cerita rakyat Musi Rawas. Teknik pengumpulan data menggunakan teknik tes, observasi, dan dokumentasi. Penelitian dilaksanakan dalam dua siklus, setiap siklus dirancang dengan rincian kegiatan setiap pertemuan sebagai berikut: (1) perencanaan, (2) tindakan, (3) observasi, dan (4) refleksi. Uji keabsahan data menggunakan triangulasi. Hasil penelitian ini menunjukkan bahwa terjadi peningkatkan kemampuan menulis naskah drama siswa kelas VIII SMP Negeri Pedang dengan menggunakan pendekatan kontekstual berbasis cerita rakyat Musi Rawas. Hal ini ditunjukkan dengan peningkatan hasil belajar dari siklus 1 ke siklus 2. Pada siklus 1 siswa
\end{abstract}


Peningkatan Kemampuan Menulis Naskah Drama melalui Pendekatan Kontekstual ...

yang tuntas sebesar $44,5 \%$ dengan kategori cukup dan terjadi peningkatan pada siklus 2 dengan jumlah siswa yang tuntas $86,1 \%$ dengan kategori baik.

Kata kunci: Menulis Naskah Drama, Pendekatan Kontekstual, Cerita Rakyat

\section{PENDAHULUAN}

Kemampuan menulis dalam pembelajaran bahasa Indonesia menuntut siswa untuk berpikir logis yang dapat diterapkan dalam kehidupan sehari-hari. Kurikulum 2013, dalam pembelajaran bahasa Indonesia adalah berbasis teks atau naskah. Naskah merupakan ungkapan pikiran manusia yang lengkap dengan situasi dan konteks. Di dalam naskah tersebut diharapkan siswa mampu mengembangkan kecerdasan berpikir dan mengekspresikan diri.

Tarigan (2008:3) menjelaskan menulis merupakan suatu keterampilan berbahasa yang digunakan untuk berkomunikasi secara langsung atau secara tidak langsung atau secara tidak bertatap muka dengan orang lain, menulis merupakan suatu kegiatan yang produktif dan ekspresif dalam penerapan ilmu pengetahuan dan informasi, baik secara formal maupun non formal. Pembelajaran Kurikulum 2013, khususnya pelajaran Bahasa Indonesia merupakan pembelajaran berbasis teks yang bertujuan agar dapat membawa siswa sesuai perkembangan mentalnya, menyelesaikan kehidupan nyata dengan berpikir kritis. Permendikbud Nomor 58 tahun 2014 menerangkan bahwa penerapan pembelajaran bahasa Indonesia harus memiliki prinsip, yaitu: (a) bahasa hendaknya dipandang sebagai teks, bukan semata-mata sebagai kumpulan kata-kata atau kaidah kebahasaan, (b) penggunaan bahasa merupakan proses pemilihan bentuk kebahasaan untuk mengungkap makna, (c) bahasa bersifat fungsional, artinya penggunaan bahasa tidak pernah dipisahkan dari konteks karena bentuk bahasa yang digunakan mencerminkan ide, sikap, nilai, dan ideologi penggunaan bahasa tersebut, dan (d) bahasa merupakan sarana pembentukan berpikir manusia.

Mengacu pada prinsip di atas, pada kompetensi menulis yaitu materi pembelajaran menulis naskah drama yang harus dipelajari siswa di SMP membawa pada metode pembelajaran yang bertahap dari kegiatan guru membangun konteks, dilanjutkan kegiatan contoh teks, sampai dengan membuat teks secara mandiri. Pembelajaran berbasis naskah pada faktanya menunjukkan bahwa manusia hidup dengan komunikasi, maka dengan komunikasi manusia memerlukan kata-kata yang sesuai materi pembicaraan atau wacana yang ada dengan itu seseorang telah menciptakan naskah sesuai pengalaman sehari-hari. Dalam Kurikulum 2013 terdapat jenis pembelajaran membuat naskah drama. Naskah drama merupakan bagian dari karya sastra yang memiliki ciri khas yaitu penggunaan dialog yang menarik. Nakah drama sebagai karya sastra juga harus mampu memiliki nilai manfaat dan keindahan yang tidak dapat dipisahkan dengan pengajaran bahasa dan sastra karena keduanya saling membangun, terutama dalam pengajaran bahasa selalu menggunakan karya sastra sebagai objek utamanya dalam menjelaskan fungsi dan ciri bahasa tersebut (Noermanzah, 2017:28).

Salah satu kompetensi yang harus dicapai siswa terdapat pada KD 4.16 menyajikan drama dalam bentuk naskah. Nurgiyantoro (2010:23) menjelaskan bahwa kemampuan menulis naskah drama dengan memperhatikan unsur intrinsik drama seperti dialog, alur, latar, tokoh, imajinasi dan amanat. Jadi, apabila siswa 
telah mencapai kompetensi tersebut, maka siswa telah mampu menyusun teks drama tersebut.

Pembelajaran menulis naskah drama itu penting karena dapat menjadi media ekspresi bagi siswa sehingga dengan drama siswa bisa lebih diarahkan untuk mengekspresikan pikiran dan perasaannya melalui kebiasaan yang positif dan bernilai karena drama dapat menjadi suatu kebiasaan yang dapat menjadikan siswa lebih kreatif. Menulis adalah ungkapkan perasaan dan pikiran yang menuntut adanya latihan dan membutuhkan ketelitian, pengetahuan yang luas, dan pola pikir yang logis (Noermanzah, 2018:116). Pengetahuan yang luas tidak terlepas dari kegiatan membaca, maka menulis harus diimbangi dengan kegiatan membaca. Itulah sebabnya menulis merupakan keterampilan menggunakan bahasa dalam bentuk tertulis sebagai hasil dari keterampilan mendengar, berbicara, dan membaca.

Teknis penulisan naskah drama memiliki kekhususan jika dibandingkan dengan teknis penulisan puisi atau prosa karena memiliki kemungkinan untuk dipentaskan. Naskah drama adalah salah satu genre karya sastra yang sejajar dengan prosa dan puisi, naskah drama memiliki bentuk sendiri yang ditulis dalam bentuk dialog yang didasarkan atas konflik batin dan mempunyai kemungkinan dipentaskan (Waluyo, 2003: 2). Naskah drama juga sebagai ungkapan penulis yang berisi nilai-nilai pengalaman umum juga merupakan ide dasar bagi aktor (Sendrasik, 2017: 42 ). Menulis naskah drama yaitu menuangkan ide dan gagasan yang ada dalam tulisan dari objek yang dilihat atau diamati yang mengisahkan suatu kejadian sehingga menarik perhatian pembaca melalui kekuatan dialog (Mulyati, 2007: 27).

Untuk mencapai kemampuan menulis naskah drama sesuai konsepnya, siswa masih mengalami kesulitan dalam menulis naskah drama karena keterbatasan kemampuan mengekspresikan suatu cerita berupa naskah, sehingga masih sedikit siswa yang memperoleh nilai sesuai KKM (Kriteria Ketuntasan Minimal) bahkan banyak siswa yang nilainya masih di bawah KKM. Kendala ini juga dikarenakan adanya beberapa faktor yaitu pembelajaran menulis drama bagi sebagian besar siswa belum begitu menguasai dalam memberikan deskripsi cerita, ada kalanya idenya sudah bagus, tetapi penulisan gambaran cerita yang dibuat tidak berhubungan.

Berdasarkan observasi awal peneliti menurut pendapat dari beberapa siswa salah satunya bernama Kesya Afifah yang mengatakan pembelajaran menulis naskah drama sangat membingungkan karena ia tidak tahu bagaimana cara memulainya dan mengambarkan serta mengembangkan ide cerita dan faktor lainnya. Hal ini adalah kekurangan guru dalam menyajikan materi serta teknis mengajar menulis naskah drama yang tidak bervariasi. Guru hanya memberikan penugasan dalam menulis drama tanpa ada usaha untuk membantu siswa dalam memunculkan ide atau gagasan yang ada dalam pikiran siswa serta upaya lain yang kurang mendukung. Tidak adanya alat bantu berupa benda yang diperlihatkan untuk memotivasi kreativitas siswa dalam menuangkan ide atau gagasan.

Kemampuan menulis naskah drama berdasarkan cerita rakyat Musi Rawas difokuskan pada tokoh, latar, tema, amanat, dialog, dan konflik. Tokoh atau aktor berdialog dalam naskah drama tersebut, latar tempat atau waktu dalam naskah drama tersebut, tema merupakan ide pokok dari naskah drama, amanat yang dapat kita ambil dari cerita rakyat Musi Rawas, kita diajarkan untuk harus rela berkorban demi bangsa dan negara dan ikhlas dalam kehidupan ini. Dialog adalah percakapan dua orang atau lebih dalam cerita dalam hal ini naskah drama berdasarkan cerita rakyat Musi Rawas, konflik pertikaian yang terjadi pada drama tersebut. Siswa 
supaya lebih fokus dalam menulis naskah drama, penulis menyiapkan cerita rakyat Musi Rawas yang akan menjadi panduan dalam menulis naskah drama diharapkan siswa mampu menuliskan naskah drama dan lebih menyenangi kegiatan menulis drama sehingga menumbuhkan sikap positif bagi dirinya dan siswa lebih minat menulis.

Berdasarkan kondisi nyata di kelas upaya untuk meningkatkan kemampuan menulis naskah drama siswa di kelas, peneliti menggunakan Penelitian Tindakan Kelas (PTK) sebagai salah satu upaya yang dapat dilakukan pendidik untuk meningkatkan kualitas peran dan tanggung jawabnya sebagai pendidik, khususnya dalam pengelolaan pembelajaran yang mengutamakan proses dan hasil (Sanjaya, 2013:65). Proses penelitian menggunakan pendekatan kontekstual yang lebih dikenal dengan Contextual Teaching and Learning (CTL). CTL adalah konsep dasar yang mendorong guru untuk menghubungkan antara materi yang diajarkan dengan situasi dunia nyata siswa (Nurhadi, 2014:82). Kemudian, Kunandar (2007:295) mengemukakan pembelajaran Contextual Teaching Learning (CTL) yang intinya membantu guru untuk mengaitkan materi pelajaran dan apa yang dipelajari dikaitkan dengan kehidupan siswa sehari-hari. Dalam penelitian ini, pendekatan kontekstual yang digunakan yaitu cerita rakyat Musi Rawas yang bertujuan agar siswa lebih mampu memahami peristiwa yang ia alami dalam kesehariannya. Cerita rakyat Musi Rawas ini nantinya digunakan sebagai sarana untuk membuat naskan drama.

Penelitian tentang pendekatan kontekstual sudah pernah diterapkan oleh Sugiharta (2011) berjudul Peningkatan Kemampuan Menulis Naskah Drama dengan Menggunakan Media Teks Berita pada Siswa Kelas VIII A SMP Negeri 10 Probolinggo. Berbeda dengan penelitian ini pelaksanaan lebih konstektual karena berbasis cerita rakyat yang mana tempat penulis tinggal yaitu Musi Rawas karena lebih benar-benar dirasakan peneliti dan siswa sebagai objek penelitian terutama dari segi bahasa. Jadi, belum dilakukannya penelitian tentang penerapan pendekatan konstektual berbasis cerita rakyat Musi Rawas untuk meningkatkan kemampuan menulis naskah drama siswa kelas VIII SMP Negeri Pedang Tahun Pelajaran 2018/2019.

\section{METODE}

Penelitian ini menggunakan metode penelitian tindakan kelas (PTK). Model penelitian tindakan yang digunakan yaitu model Hopkins dengan langkah-langkah penelitian yaitu: perencanaan, pelaksanaan, pengamatan, dan refleksi (Sanjaya, 2013:53). Tempat penelitian dilakukan di Kelas VIII SMP Negeri Pedang Jl. Lintas Sumatera KM 12,5 Desa Pedang Kecamatan Muara Beliti Kabupaten Musi Rawas tahun pelajaran 2018/2019. Teknik pengumpulan data menggunakan teknik observasi, dokumentasi, dan teknis tes. Observasi dilakukan dengan pedoman observasi kegiatan guru dan siswa dalam proses pembelajaran sedangkan tes berupa tes unjuk kerja menulis naskah drama dengan indikator penilaian difokuskan pada kemampuan dalam menuangkan tokoh, latar, tema, amanat, dialog, dan konflik.

Teknik analisis data dengan cara menganalisis data observasi kegiatan pembelajaran, menganalisis dokumentasi, dan menganalisis hasil tes kemampuan menulis naskah drama, dan membuat kesimpulan sesuai indikator keberhasilan PTK. Indikator keberhasilan PTK, yaitu: 1) secara individual siswa dinyatakan berhasil jika memperoleh nilai kemampuan menulis naskah drama minimal nilai $\geq 70$, dan secara klasikal $85 \%$ siswa memperoleh nilai rata-rata $\geq 70$. Kemudian, 2) aktivitas siswa 
dalam proses pembelajaran menulis naskah drama dinyatakan berhasil jika memperoleh nilai dari minimal cukup aktif menjadi aktif atau sangat aktif. Uji keabsahan data menggunakan triangulasi sumber data yang berasal dari observasi, dokumentasi, dan tes kemampuan menulis naskah drama.

\section{HASIL}

Hasil kemampuan menulis naskah drama melalui pendekatan kontekstual berbasis cerita rakyat Musi Rawas siswa kelas VIII SMP Negeri Pedang dapat dijelaskan per siklus sebagai berikut.

1. Siklus 1

Pada tahap refleksi ini, 2 peneliti mendiskusikan temuan selama proses pembelajaran berlangsung. Hasil pengamatan pada tahap siklus 1 yaitu: (1) siswa sudah mulai aktif selama pembelajaran berlangsung, (2) beberapa siswa sudah dapat memahami tentang aspek-aspek yang ada dalam drama yang disajikan baik aspek tokoh, latar, tema, amanat, dialog dan konflik, dan (3) nilai rata-rata yang diperoleh siswa pada siklus ini sudah termasuk kategori cukup yaitu tedapat 16 siswa yang tuntas dari 36 siswa dengan persentase $44,5 \%$.

\section{Siklus 2}

Siswa yang mengikuti tes sebanyak 36 siswa, jumlah siswa yang mendapat nilai sangat baik dengan kategori skor 12 - 15 berjumlah 14 siswa atau 38,8\%, siswa yang mendapat nilai baik dengan kategori skor $8-11$ berjumlah 22 siswa atau $61,1 \%$ dansiswa yang mendapat nilai cukup dengan kategori skor 5 - 9 serta siswa yang nilai kurang dengan kategori skor $0-4$ tidak ada atau $0 \%$. Dari data yang sudah ada maka jumlah nilai yang didapat dari aspek konflik sebesar 407 dengan rata-rata nilai siswa 11,3 dengan kategori baik. Jadi, dapat dikatakan bahwa kemampuan siswa kelas VIII SMP Negeri Pedang Musi Rawas dalam menulis naskah drama berdasarkan cerita rakyat Musi Rawas dengan aspek konflik sudah baik. Siswa yang mengikuti tes sebanyak 36 siswa, jumlah siswa dengan kategori baik sebanyak 31 siswa sedangkan dengan kategori cukup sebanyak 5 siswa. Berdasarkan data nilai evaluasi siswa dilihat dari jumlah siswa yang mendapat nilai rata-rata yang diperoleh sebesar 76,4. Hal ini menunjukkan bahwa kemampuan menulis naskah drama berdasarkan cerita rakyat Musi Rawas di kelas VIII SMP Negeri Pedang Musi Rawas dengan kategori baik.

Dari hasil tes kemampuan menulis naskah drama nilai rata-rata 76,4 . Siswa yang mendapat nilai lebih dari atau sama dengan 75 sebanyak 31 siswa, dan 5 siswa mendapat nilai kurang dari 75.

Tabel 1. Hasil Tes Menulis Naskah Drama

\begin{tabular}{||cccc||}
\hline $\begin{array}{c}\text { Tingkat } \\
\text { Penguasaan }\end{array}$ & Jumlah Siswa & $\begin{array}{c}\text { Kategori } \\
\text { Penilaian }\end{array}$ & Persentase \\
\hline \hline $85-100$ & - & Sangat Baik & - \\
\hline \hline $75-84$ & 31 & Baik & $86,1 \%$ \\
\hline \hline $60-74$ & 5 & Cukup & $13,9 \%$ \\
\hline \hline $40-59$ & - & Kurang & - \\
\hline \hline $0-39$ & - & Sangat Kurang & - \\
\hline
\end{tabular}


Berdasarkan hasil tes tingkat penguasaan baik, rentang nilai $75-84$ sebanyak 31 siswa atau 86,1, tingkat penguasaan cukup rentang penilaian $60-74$ sebanyak 5 siswa atau 13,9, tingkat penguasaan kurang rentang penilaian $40-59$, dan tingkat penguasaan sangat kurang dengan rentang penilaian $0-39$ sebanyak 0 siswa atau $0 \%$.

\section{PEMBAHASAN}

Berdasarkan hasil penelitian menunjukkan terjadinya peningkatan kemampuan menulis naskah drama melalui pendekatan kontekstual berbasis cerita rakyat Musi Rawas siswa kelas VIII SMP Negeri Pedang. Hal ini ditunjukkan dengan peningkatan hasil belajar dari siklus 1 ke siklus 2. Pada siklus 1 siswa yang tuntas sebesar $44,5 \%$ dengan kategori cukup dan terjadi peningkatan pada siklus 2 dengan jumlah siswa yang tuntas $86,1 \%$ dengan kategori baik. Keberhasilan PTK ini menujukkan bahwa pendekatan kontekstual berbasis cerita rakyat Musi Rawas mampu memotivasi siswa untuk menulis naskah drama dengan baik. Hal ini sesuai dengan pendapat Kunandar (2007:295) bahwa pendekatan kontekstual membantu guru untuk mengaitkan materi pelajaran dan apa yang dipelajari dikaitkan dengan kehidupan siswa sehari-hari. Dengan cara ini, siswa lebih mudah menuangkan gagasannya dalam menulis naskah drama karena bantuan cerita rakyat Musi Rawas yang sudah dikenal dalam keseharian siswa.

Keberhasilan peningkatan kemampuan menulis naskah drama ini juga tidak terlepas dari peran guru sebagai fasilitator. Hal ini sesuai dengan pendapat Noermanzah (2015:274) bahwa peran tenaga pengajar bahasa Indonesia yaitu harus mampu menciptakan pembelajaran yang kreatif, inovatif, dan menyenangkan sehingga siswa mampu juga kreatif, berkolaboratif, komunikatif, dan berpikir kritis dalam melaksanakan kegiatan pembelajaran sesuai dengan tujuan yang diharapkan dalam kurikulum.

Kemudian, peningkatan kemampuan menulis naskah drama juga ditunjukkan pada setiap unsur naskah drama, dimulai dari tokoh, latar, tema, amanat, dialog, dan konflik. Kita mulai dengan unsur tokoh. Tokoh merupakan aspek pertama dalam aspek penilaian kemampuan menulis naskah drama berdasarkan cerita rakyat Musi Rawas, tokoh menyangkut kemampuan siswa menguasai untuk menyampaikan karakter dan kemampuan untuk menulis tokoh-tokoh sesuai karakter yang diinginkan. Berdasarkan analisis data, kemampuan menulis naskah drama berdasarkan cerita rakyat Musi Rawas di kelas VIII SMP Negeri Pedang Musi Rawas dari aspek tokoh dikategorikan sangat baik, karena rata-rata nilai yang diperoleh dengan skor sangat baik 12-15 berjumlah 28 siswa dari 36 total jumlah siswa sedangkan siswa yang mendapat nilai baik dengan skor $8-11$ sebanyak 8 siswa dari 36 total jumlah siswa. Sedangkan siswa yang mendapat nilai cukup dengan skor $5-7$ dan siswa yang mendapat nilai kurang dengan skor $0-4$ tidak ada.

Berdasarkan analisis data kemampuan menulis naskah drama, dapat dilihat bahwa kemampuan menulis naskah drama berdasarkan cerita rakyat Musi Rawas di kelas VIII SMP Negeri Pedang Musi Rawas dari aspek tokoh terbagi atas 28 orang siswa dengan klasifikasi nilai atau kategori sangat baik, 8 orang siswa dengan klasifikasi atau kategori baik, dan nilai cukup dan kurang tidak ada. Kemudian, dari hasil analisis data yang telah dilakukan pada aspek tokoh, kebanyakan siswa sudah dapat membuat naskah drama berdasarkan cerita rakyat Musi Rawas secara baik, sesuai dengan kategori penilaian dalam aspek tokoh, seperti informasi yang 
disajikan lengkap, jelas, padat dan sesuai dengan topik penilaian yang telah ditetapkan, hanya saja siswa kelas VIII SMP negeri Pedang Musi Rawas tidak menulis tujuan dari tokoh yang seharusnya sudah harus tergambar di naskah drama tersebut.

Latar merupakan aspek kedua dalam penilaian kemampuan menulis naskah drama berdasarkan cerita rakyat Musi Rawas, latar menyangkut kemampuan siswa menguasai untuk menyampaikan tempat kejadian peristiwa. Latar disesuaikan dengan situasi dan kondisi yang terjadi saat itu, misalnya latar tempat yang menyatakan tempat kejadian peristiwa dalam hal ini bisa di kota atau desa atau tempat lain di mana peristiwa itu terjadi. Latar suasana, misalnya sedih, marah, haru, gembira, dan sebagainya. Hal ini sesuai dengan dengan kemampuan untuk untuk menulis latar sesuai karakter yang diinginkan berdasarkan cerita rakyat Musi Rawas.

Analisis data, kemampuan menulis naskah drama berdasarkan cerita rakyat Musi Rawas di kelas VIII SMP Negeri Pedang Musi Rawas dari aspek Latar dikategorikan sangat baik, karena rata-rata nilai yang diperoleh dengan skor sangat baik 12 - 15 berjumlah 29 siswa dari 36 total jumlah siswa sedangkan siswa yang mendapat nilai baik dengan skor 8 - 11 sebanyak 7 siswa dari 36 total jumlah siswa. Sedangkan siswa yang mendapat nilai cukup dengan skor $5-7$ dan siswa yang mendapat nilai kurang dengan skor 0 - 4 tidak ada.

Kemampuan menulis naskah drama berdasarkan cerita rakyat Musi Rawas di kelas VIII SMP Negeri Pedang Musi Rawas dari aspek latar terbagi atas 29 orang siswa dengan klasifikasi nilai sangat baik, 7 orang siswa dengan klasifikasi nilai baik dan nilai cukup dan kurang tidak ada. Hasil analisis data yang telah dilakukan pada aspek latar, kebanyakan siswa sudah dapat membuat naskah drama berdasarkan cerita rakyat Musi Rawas secara baik, sesuai dengan kategori penilaian dalam aspek tokoh atau penokohan, seperti informasi yang disajikan lengkap, jelas, padat dan sesuai dengan topik penilaian yang telah ditetapkan hanya saja siswa kelas VIII SMP Negeri Pedang Musi Rawas tidak menuliskan tujuan dari tokoh yang seharusnya sudah harus tergambar di dalam naskah drama tersebut.

Tema merupakan aspek ketiga dalam aspek penilaian kemampuan menulis naskah drama berdasarkan cerita rakyat Musi Rawas, tema menyangkut kemampuan siswa menguasai topik. Analisis data, kemampuan menulis naskah drama berdasarkan cerita rakyat Musi Rawas di kelas VIII SMP Negeri Pedang Musi Rawas dari aspek alur atau plot dikategorikan sangat baik, karena rata-rata nilai yang diperoleh dengan skor sangat baik $15-20$ berjumlah 22 siswa dari 36 total jumlah siswa sedangkan siswa yang mendapat nilai baik dengan skor $10-14$ sebanyak 14 siswa dari 36 total jumlah siswa. Sedangkan siswa yang mendapat nilai cukup dengan skor $5-9$ dan siswa yang mendapat nilai kurang dengan skor $0-4$ tidak ada.

Berdasarkan perhitungan di atas, dapat dilihat bahwa kemampuan menulis naskah drama berdasarkan cerita rakyat Musi Rawas di kelas VIII SMP Negeri Pedang Musi Rawas dari aspek tema terbagi atas 22 orang siswa dengan klasifikasi nilai sangat baik, 14 orang siswa dengan klasifikasi nilai baik, dan nilai cukup dan kurang tidak ada. Kemudian, dari hasil analisis data yang telah dilakukan pada aspek tema kebanyakan siswa sudah dapat membuat naskah drama berdasarkan cerita rakyat Musi Rawas secara baik, sesuai dengan kategori penilaian dalam aspek tema, seperti informasi yang disajikan lengkap, jelas, padat, dan sesuai dengan topik penilaian yang telah ditetapkan di kelas VIII SMP Negeri Pedang Musi Rawas. 
Amanat merupakan aspek keempat dalam aspek penilaian kemampuan menulis naskah drama berdasarkan cerita rakyat Musi Rawas, amanat menyangkut kemampuan siswa menguasai untuk menyampaikan kemampuan topik atau apa yang harus didapat oleh pembaca naskah drama atau dengan kata lain adakah nasehat yang dapat diterapkan di kehidupan bermasyarakat atau diri sendiri, amanat bisa tersirat, dan bisa tersurat. Selanjutnya, kemampuan menulis naskah drama berdasarkan cerita rakyat Musi Rawas di kelas VIII SMP Negeri Pedang Musi Rawas dari aspek latar atau setting dikategorikan sangat baik, karena rata-rata nilai yang diperoleh dengan skor sangat baik 12 - 15 berjumlah 20 siswa dari 36 total jumlah siswa sedangkan siswa yang mendapat nilai baik dengan skor $8-11$ sebanyak 16 siswa dari 36 jumlah siswa. Sedangkan siswa yang mendapat nilai cukup dengan skor $5-7$ dan siswa yang mendapat nilai kurang dengan skor $0-4$ tidak ada.

Kemampuan menulis naskah drama berdasarkan cerita rakyat Musi Rawas di kelas VIII SMP Negeri Pedang Musi Rawas dari aspek amanat terbagi atas 20 orang siswa dengan klasifikasi nilai sangat baik, 16 orang siswa dengan klasifikasi nilai baik, dan nilai cukup dan kurang tidak ada. Hasil analisis data yang telah dilakukan pada aspek amanat kebanyakan siswa sudah dapat membuat naskah drama berdasarkan cerita rakyat Musi Rawas dengan aspek amanat dengan kategori baik dengan nilai rata - rata 11,2 seperti informasi yang disajikan lengkap, jelas, padat, dan sesuai dengan topik penilaian yang telah ditetapkan.

Dialog merupakan aspek kelima dalam aspek penilaian kemampuan menulis naskah drama berdasarkan cerita rakyat Musi Rawas, dialog menyangkut kemampuan siswa menguasai untuk menyampaikan dialog atau komunikasi antar dua tokoh atau lebih agar komunikasi antar tokoh dapat terbangun sehingga terciptanya komunikasi yang baik. Hal ini sesuai dengan kemampuan untuk menulis diolag sesuai karakter yang diinginkan berdasarkan cerita rakyat.

Kemampuan menulis naskah drama berdasarkan cerita rakyat Musi Rawas di kelas VIII SMP Negeri Pedang Musi Rawas dari aspek imajinasi dikategorikan sangat baik, karena rata-rata nilai yang diperoleh dengan skor sangat baik $12-15$ berjumlah 19 siswa dari 36 jumlah siswa sedangkan siswa yang mendapat nilai baik dengan skor 8 - 11 sebanyak 17 siswa dari 36 jumlah siswa. Sedangkan siswa yang mendapat nilai cukup dengan skor $5-7$ dan siswa yang mendapat nilai kurang dengan skor 0 - 4 tidak ada. Kemampuan menulis naskah drama berdasarkan cerita rakyat Musi Rawas di kelas VIII SMP Negeri Pedang Musi Rawas dari aspek dialog terbagi atas 19 orang siswa dengan klasifikasi nilai sangat baik, 17 orang siswa dengan klasifikasi nilai baik, dan nilai cukup dan kurang tidak ada.

Hasil analisis data yang telah dilakukan pada aspek dialog kebanyakan siswa sudah dapat membuat naskah drama berdasarkan cerita rakyat Musi Rawas secara baik sesuai dengan kategori penilaian dalam aspek dialog, seperti informasi yang disajikan lengkap, jelas, padat dan sesuai dengan topik penilaian yang telah ditetapkan. Amanat merupakan aspek terakhir dalam aspek penilaian kemampuan menulis naskah drama berdasarkan cerita rakyat Musi Rawas, konflik menyangkut kemampuan siswa menguasai konflik atau pertentangan antar tokoh sehingga setelah munculnya konflik dapat terselesaikan dengan baik.

Kemampuan menulis naskah drama berdasarkan cerita rakyat Musi Rawas di kelas VIII SMP Negeri Pedang Musi Rawas dari aspek konflik dikategorikan sangat baik, karena rata-rata nilai yang diperoleh dengan skor sangat baik 12 - 15 berjumlah 14 siswa dari 36 jumlah siswa sedangkan siswa yang mendapat nilai baik 
dengan skor 8 - 11 sebanyak 22 siswa dari 36 jumlah siswa. Sedangkan siswa yang mendapat nilai cukup dengan skor $5-7$ dan siswa yang mendapat nilai kurang dengan skor $0-4$ tidak ada.

Kemampuan menulis naskah drama berdasarkan cerita rakyat Musi Rawas di kelas VIII SMP Negeri Pedang Musi Rawas dari aspek konflik terbagi atas 14 orang siswa dengan klasifikasi nilai sangat baik, 22 orang siswa dengan klasifikasi nilai baik, dan nilai cukup dan kurang tidak ada. Hasil analisis data yang telah dilakukan pada aspek amanat siswa sudah dapat membuat naskah drama berdasarkan cerita rakyat Musi Rawas dengan baik sesuai dengan kategori penilaian dalam aspek amanat, seperti informasi yang disajikan lengkap, jelas, padat, dan sesuai dengan topik penilaian yang telah ditetapkan. Jadi, kemampuan menulis naskah drama siswa berdasarkan cerita rakyat Musi Rawas di kelas VIII SMP Negeri Pedang Musi Rawas dengan aspek konflik sangat baik dengan nilai rata - rata 11,3.

Hasil analisis data yang telah dilakukan, menunjukkan bahwa kemampuan menulis naskah drama berdasarkan cerita rakyat Musi Rawas di kelas VIII berkategori baik. Hal ini berdasarkan hasil tes dengan tingkat penguasaan dengan kategori tingkat penguasaan dengan kategori baik, rentang nilai 75 - 84 sebanyak 31 siswa, dengan nilai rata - rata 86,1, tingkat penguasaan dengan kategori cukup, rentang nilai 60 - 74 sebanyak 5 siswa, dengan nilai rata - rata 13,9. tingkat penguasaan kurang, rentang penilaian 40 - 59 dan tingkat penguasaan sangat kurang dengan rentang penilaian 0 - 39 sebanyak 0 siswa. Dari data di atas menunjukkan bahwa kemampuan menulis naskah drama berdasarkan cerita rakyat Musi Rawas di kelas VIII SMP Negeri Pedang Musi Rawas dengan nilai rata-rata 76,4 dengan kategori baik.

\section{KESIMPULAN DAN SARAN}

Berdasarkan hasil penelitian dan pembahasan, dapat disimpulkan bahwa terjadi peningkatkan kemampuan menulis naskah drama siswa kelas VIII SMP Negeri Pedang dengan menggunakan pendekatan kontekstual berbasis cerita rakyat Musi Rawas. Hal ini ditunjukkan dengan peningkatan hasil belajar dari siklus $1 \mathrm{ke}$ siklus 2. Pada siklus 1 siswa yang tuntas sebesar $44,5 \%$ dengan kategori cukup dan terjadi peningkatan pada siklus 2 dengan jumlah siswa yang tuntas $86,1 \%$ dengan kategori baik. Dari hasil penelitian ini, diharapkan pendekatan kontekstual berbasis cerita rakyat Musi Rawas dapat dijadikan salah satu cara bagi guru bahasa Indonesia dalam meningkatkan kemampuan menulis naskah drama.

\section{DAFTAR PUSTAKA}

Kunandar. 2007. Guru Profesional: Implementasi Kurikulum Tingkat Satuan Pendidikan (KTSP) dan Sukses dalam Sertifikasi Guru. Jakarta: Rajagrafindo Persada.

Mulyati, Y. (2007). Keterampilan Berbahasa Indonesia SD. Jakarta: Universitas Terbuka.

Noermanzah, N. (2015). Peran Dosen Bahasa dan Sastra Indonesia dalam Mempertahankan Bahasa Indonesia sebagai Alat Pemersatu Negara Kesatuan Republik Indonesia pada Era Globalisasi. In Prosiding Seminar Nasional Bulan 
Peningkatan Kemampuan Menulis Naskah Drama melalui Pendekatan Kontekstual ...

Bahasa 2015. Unit Penerbitan FKIP Universitas Bengkulu, p. 274. http://repository.unib.ac.id/11133/

Noermanzah, N., Abid, S., \& Septaria, S. (2018). Improving the Ability of Writing a Narrative Charge by Using Animated Images Media Student Class V.B SD Negeri 17 Lubuklinggau. BAHTERA : Jurnal Pendidikan Bahasa dan Sastra, 17(2), 116. doi:10.21009/bahtera.172.9

Noermanzah, N. (2017). Plot in a Collection of Short Stories "Sakinah Bersamamu" works of Asma Nadia with Feminimism Analysis. Humanus: Jurnal IImiah IImuilmu Humaniora, 16(1), 28. https://doi.org/10.24036/jh.v16i1.7015

Nurgiyantoro, B. (2010). Penilaian dalam Pengajaran Bahasa dan Sastra. Yogyakarta: Gajah Mada Universitas Press.

Nurhadi. (2014). Pembelajaran Kontekstual (Contextual Teaching and Learning) dan Penerapan dalam KBK. Malang: UM Press.

Permendikbud RI, Nomor 58, Tahun 2014, tentang Kurikulum 2013 Sekolah Menengah Pertama/Madrasah Tsanawiyah.

Sanjaya, W. (2013). Penelitian Tindakan Kelas. Jakarta: Prenada Media.

Sendrasik. (2017). Pengertian Naskah Drama Menurut Ahli. http://ofteachers.blogsport.com/2017/04/-Pengertian-naskah-drama-menurut para ahli..html

Sugiharta, N. (2011). Peningkatan Kemampuan Menulis Naskah Drama dengan Menggunakan Media Teks Berita pada Siswa Kelas VIII A SMP Negeri 10 Probolinggo. SKRIPSI Jurusan Sastra Indonesia - Fakultas Sastra UM.

Tarigan, H. G. (2008). Menulis sebagai Suatu Keterampilan Berbahasa. Bandung: Angkasa.

Waluyo, H. J. (2003). Pengkajian Sastra Rekaan. Salatiga: Widyasari Press.

Wina. (2016). Pengertian Penelitian Tindakan Kelas Menurut Para Ahli. http://www.seputar pengetahuan .co.id/2016/04/12-pengertian-penelitian tindakan- kelas- menurut- para- ahli.html 